\title{
CRITICAL LIBRARIANSHIP
}




\section{ADVANCES IN LIBRARY ADMINISTRATION AND ORGANIZATION}

\section{Series Editor: Samantha Schmehl Hines}

\section{Recent volumes:}

Volume 1: $\quad$ Edited by W. Carl Jackson, Bernard Kreissman and Gerard B. McCabe

Volumes 2-12: $\quad$ Edited by Bernard Kreissman and Gerard B. McCabe

Volumes 13-20: $\quad$ Edited by Edward D. Garten and Delmus E. Williams

Volume 21-24: $\quad$ Edited by Edward D. Garten, Delmus E. Williams and James M. Nyce

Volume 25: $\quad$ Edited by Edward D. Garten, Delmus E. Williams, James M. Nyce and Sanna Talja

Volume 26: $\quad$ Edited by Edward D. Garten, Delmus E. Williams, James M. Nyce and Janine Golden

Volume 27: $\quad$ Edited by William Graves III, James M. Nyce, Janine Golden and Delmus E. Williams

Volume 28: $\quad$ Edited by Delmus E. Williams, James M. Nyce and Janine Golden

Volume 29-32: $\quad$ Edited by Delmus E. Williams and Janine Golden

Volume 33: $\quad$ Edited by Delmus E. Williams, Janine Golden and Jennifer K. Sweeney

Volume 34: $\quad$ Edited by Samantha Schmehl Hines and Marcy Simons

Volume 35: $\quad$ Edited by David Baker and Wendy Evans

Volume 36: $\quad$ Edited by Samantha Schmehl Hines and Kathryn Moore Crowe

Volume 37: $\quad$ Edited by Samantha Schmehl Hines and Miriam Matteson

Volume 38: $\quad$ Edited by Samantha Schmehl Hines and Alice Daugherty

Volume 39: $\quad$ Edited by Samantha Schmehl Hines and George J. Fowler

Volume 40: $\quad$ Edited by Samantha Schmehl Hines and Janet A Crum 
ADVANCES IN LIBRARY ADMINISTRATION AND ORGANIZATION VOLUME 41

\title{
CRITICAL LIBRARIANSHIP
}

\author{
EDITED BY \\ SAMANTHA SCHMEHL HINES \\ Peninsula College, USA \\ DAVID H. KETCHUM \\ University of Oregon, USA
}

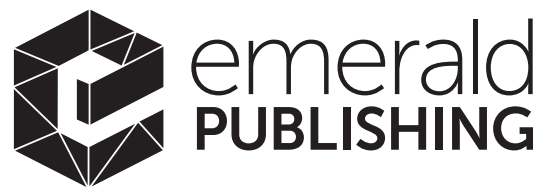

United Kingdom - North America - Japan

India - Malaysia - China 
Emerald Publishing Limited

Howard House, Wagon Lane, Bingley BD16 1WA, UK

First edition 2020

Chapter 6 @ 2020 Jade Alburo, Agnes K. Bradshaw, Ariana E. Santiago, Bonnie Smith, and Jennifer Vinopal. Published under an exclusive licence. Free to use for academic purposes.

All other Chapters and Editorial Matter (C) Emerald 2020

\section{Reprints and permissions service}

Contact: permissions@emeraldinsight.com

No part of this book may be reproduced, stored in a retrieval system, transmitted in any form or by any means electronic, mechanical, photocopying, recording or otherwise without either the prior written permission of the publisher or a licence permitting restricted copying issued in the UK by The Copyright Licensing Agency and in the USA by The Copyright Clearance Center. Any opinions expressed in the chapters are those of the authors. Whilst Emerald makes every effort to ensure the quality and accuracy of its content, Emerald makes no representation implied or otherwise, as to the chapters' suitability and application and disclaims any warranties, express or implied, to their use.

\section{British Library Cataloguing in Publication Data}

A catalogue record for this book is available from the British Library

ISBN: 978-1-83909-485-9 (Print)

ISBN: 978-1-83909-484-2 (Online)

ISBN: 978-1-83909-486-6 (Epub)

ISSN: 0732-0671 (Series)

\section{ISOQAR certified}

Management System,

awarded to Emerald

for adherence to

Environmental

standard

ISOQAR

ISO 14001:2004 


\section{CONTENTS}

List of Contributors

$v i i$

Introduction: Critical Librarianship

David H. Ketchum

Theoretical and Practical Implications of Power Dynamics in Academic Libraries

Lilian Oyieke

Widening Participation Praxis and Library Leadership Andrew Preater

Feminists at Work: Organizational Leadership in Academic Libraries

Freeda Brook and Martinique Hallerduff

From Street-level Bureaucracy to Sustainable Communities:

Librarianship for Social Justice in Times of Limited Resources

Yolanda Patrice Jones

Looking Beyond Libraries for Inclusive Recruitment and Retention Practices: Four Successful Approaches

Jade Alburo, Agnes K. Bradshaw, Ariana E. Santiago,

Bonnie Smith, and Jennifer Vinopal

Countering Conformity: Embracing the "Other" and Supporting Employees with High-functioning Autism in Canadian Academic Libraries

Lori Giles-Smith and Emma Popowich

Going Back to Work: How Supervisors Can Support New Mothers as They Transition Back to the Library

Emily A. B. Swanson 
Teamwork, Emotional Intelligence, and the Skills Organizations Need Now

John A. Lehner

Author Biographies

Index 


\section{LIST OF CONTRIBUTORS}

Jade Alburo

Agnes K. Bradshaw

Freeda Brook

Lori Giles-Smith

Martinique Hallerduff

Yolanda Patrice Jones

David H. Ketchum

John A. Lehner

Lilian Oyieke

Emma Popowich

Andrew Preater

Ariana E. Santiago

Bonnie Smith

Emily A. B. Swanson

Jennifer Vinopal
University of California, Los Angeles, USA

Virginia Commonwealth University Libraries, USA

Luther College, USA

University of Manitoba, Canada

Oakton Community College, USA

Florida A\&M University College of Law, USA

University of Oregon, USA

University of Houston, USA

The Technical University of Kenya, Kenya

University of Manitoba, Canada

University of West London, UK

University of Houston, USA

University of Florida, USA

Giovale Library, Westminster College, USA

The Ohio State University, USA 